\title{
The Short Overview on the Relevance of Fatty Acids for Human Cardiovascular Disorders
}

\author{
Viktoriya S. Shramko, Yana V. Polonskaya, Elena V. Kashtanova, Ekaterina M. Stakhneva *(D) and \\ Yuliya I. Ragino $\mathbb{D}$
}

Branch of the Institute of Cytology and Genetics, Siberian Branch of Russian Academy of Sciences, Research Institute of Internal and Preventive Medicine, 630089 Novosibirsk, Russia; nosova@211.ru (V.S.S.); yana-polonskaya@yandex.ru (Y.V.P.); elekastanova@yandex.ru (E.V.K.); ragino@mail.ru (Y.I.R.)

* Correspondence: stahneva@yandex.ru; Tel./Fax: +7-(383)-264-2516

Received: 19 June 2020; Accepted: 27 July 2020; Published: 30 July 2020

\begin{abstract}
This review presents existing evidence of the influence of saturated and unsaturated fatty acids on cardiovascular diseases (CVD). Data are discussed regarding the roles of the most relevant fatty acids, such as myristic (C14:0), palmitic (C16:0), stearic (C18:0), palmitoleic (C16:1), oleic (C18:1), linoleic (C18:2), $\alpha$-linolenic (C18:3, $\omega$-3), $\gamma$-linolenic (C18:3, $\omega-6)$, arachidonic (C20:4), eicosapentaenoic (C20:5), docosahexaenoic (C22:6), and docosapentaenoic (C22:5) acid. The accumulated knowledge has expanded the understanding of the involvement of fatty acids in metabolic processes, thereby enabling the transition from basic exploratory studies to practical issues of application of these biomolecules to CVD treatment. In the future, these findings are expected to facilitate the interpretation and prognosis of changes in metabolic lipid aberrations in CVD.
\end{abstract}

Keywords: saturated fatty acid; monounsaturated fatty acid; polyunsaturated fatty acid; cardiovascular disease; blood lipid profile

\section{Introduction}

Diseases of the blood circulation system, primarily ischemic heart disease (IHD), rank first in terms of the prevalence of complications and death in Westernized societies, being responsible for one of every three deaths in the United States and one of every four deaths in Europe [1,2]. The 2013 Global Burden of Disease study estimating that cardiovascular diseases (CVD) caused 17.3 million deaths globally. It accounted for $31.5 \%$ of all deaths and $45 \%$ of all non-communicable disease deaths, more than twice that caused by cancer, as well as more than all communicable, maternal, neonatal, and nutritional disorders combined [2]. In addition to systemic inflammation, oxidative stress, and disruption of lipid metabolism, which are risk factors for the development and progression of atherosclerosis and the related CVD, fatty acid (FA) metabolic abnormalities became also an important risk factor. Much attention is given to the research on FA, with particular emphasis on the their amount and type consumed, and there are studies on potential utility of FA as biomarkers of the functional state of the human body for early diagnosis of CVD and especially atherosclerosis [3-8]. In cells of human tissues, $\sim 70$ FA have been identified as components in a structure of lipids, with more than a half of these FA detected in trace amounts, a less than $0.1 \%$ proportion.

The American Heart Association/American College of Cardiology guideline has recommended to decrease intake of saturated FA (SFA) to $5 \%$ to $6 \%$ of total daily energy (calorie) intake to reduce the risk of CVD [9]. The scientific rationale for decreasing SFA in the diet has been and remains based on well-established effects to raise low-density lipoprotein (LDL) cholesterol, along with a reduction in non-high-density lipoprotein (HDL) cholesterol, a leading causes of atherosclerosis [10]. On the contrary, polyunsaturated FA (PUFA) are considered to ameliorate lipid markers, with omega-3 PUFA 
consumption resulting in reduction of plasma triacylglycerols (TG) and ApoB-100, which in turn reduces the concentration of LDL cholesterol [11]. Reducing SFA and replacing it with PUFA in randomized controlled trials has reduced the incidence of CVD which included myocardial infarction (MI) (fatal and non-fatal combined) and IHD events [12,13]. In Finland, a successful nationwide health project to lower the very high rate of IHD mortality, started in 1972, had as a major goal the reduction in the high intake of SFA [14]. Regarding monounsaturated FA (MUFA), the data are more limited, but in vivo studies like those of Macri et al. [15], and Alsina et al. [16], found that olive oil and fish oil, rich in MUFAs, is highly effective in decreasing the oxidization of LDL, and TG levels [17]. In the populations with very low SFA intake have very low rates of CVD [18], and members of many single populations who have low SFA high unsaturated FA intake have lower future incidence of CVD compared with those with high SFA and low unsaturated FA intake [19]. Therefore, the Dietary Guidelines recent years is to shift food choices from those high in SFA to those high in MUFA and PUFA $[9,20]$.

As lipids constitute a major portion of the majority membranes suggest that the presence of massive concentrations of unsaturated FA within membranous structures. In addition, well recognized that the PUFA are bioactive mediators of diverse pathways involved in cellular homeostasis or, in some cases, interact with cellular macromolecules resulting in cell death [21]. These cellular responses may be a consequence of the vulnerability of unsaturated FA to diverse oxidation reactions, or radical reactions, or both. Reactive oxygen species readily bind to unsaturated FA in lipids that contain multiple double bonds (DB), "steal" electrons, and trigger a free radical chain reaction. This oxidative process usually consists of initiation (production of a FA radical), propagation (creation of a peroxyl-FA radical), and termination (production of electrophilic carbonyls [22,23]. The free radical mediated production of electrophilic products of PUFA proceeds by autocatalysis and is, as a result, not well regulated. Thus, free radical mediated lipid peroxidation is more commonly associated with diseases of sustained oxidative stress including atherosclerosis and the related CVD [24].

In the past few years researchers have come to discordant conclusions about the relationship between dietary FA and risk of CVD $[12,13,20]$. This has created confusion among patients, their physicians, and the public. The objective of this review is to present of results regarding effect most relevant FA on CVD, so that understand the reasons for the divergent findings.

\section{Saturated Fatty Acids (SFA)}

Among FA, the structure of SFA is the stability and their physical properties depend on their molecular weight (Table 1).

Table 1. The most physiologically important saturated fatty acids.

\begin{tabular}{cccc}
\hline $\begin{array}{c}\text { The Notation of Fatty Acid (Number } \\
\text { of Carbon Atoms: Number } \boldsymbol{\pi} \text { Bonds) }\end{array}$ & Trivial Name & Systematic Name (IUPAC) & Chemical Formula \\
\hline $12: 0$ & Lauric & Dodecanoic & $\mathrm{CH}_{3}-\left(\mathrm{CH}_{2}\right)_{10}-\mathrm{COOH}$ \\
\hline $14: 0$ & Myristic & Tetradecanoic & $\mathrm{CH}_{3}-\left(\mathrm{CH}_{2}\right)_{12}-\mathrm{COOH}$ \\
\hline $16: 0$ & Palmitic & Hexadecanoic & $\mathrm{CH}_{3}-\left(\mathrm{CH}_{2}\right)_{14}-\mathrm{COOH}$ \\
\hline $18: 0$ & Stearic & Octadecanoic & $\mathrm{CH}_{3}-\left(\mathrm{CH}_{2}\right)_{16}-\mathrm{COOH}$ \\
\hline $20: 0$ & Arachidic & Eicosanoic & $\mathrm{CH}_{3}-\left(\mathrm{CH}_{2}\right)_{18}-\mathrm{COOH}$ \\
\hline $22: 0$ & Behenic & Docosanoic & $\mathrm{CH}_{3}-\left(\mathrm{CH}_{2}\right)_{20}-\mathrm{COOH}$ \\
\hline $24: 0$ & Lignoceric & Tetracosanoic & $\mathrm{CH}_{3}-\left(\mathrm{CH}_{2}\right)_{22}-\mathrm{COOH}$ \\
\hline
\end{tabular}

SFA are resistant to oxidation. The cellular membranes and lipoproteins containing large amounts of SFA are less active functionally. Such lipoprotein particles form stable bonds with cellular receptors of lipoproteins, thus promoting disorders of the cholesterol transport system in the human body and 
leading to the development of the dyslipoproteinemias that contribute to atherosclerogenesis: So-called atherogenic dyslipoproteinemias $[25,26]$.

It is believed that consumption of food with SFA is associated with increased risk of CVD according, which is mediated by increased levels in serum of total cholesterol by increasing cholesterol levels LDL cholesterol. A number of studies have shown that increased consumption of SFA is associated with both an increased incidence of IHD and the severity of atherosclerotic lesions of the arteries [13,27-32].

A recent meta-analysis, which included 15 randomized controlled trials involving over 59,000 people, assessed the effect of reduced dietary the amount of SFA on mortality and cardiovascular morbidity [13]. This systematic review suggests that reducing SFA in the diet for at least two years reduced MI and IHD events, but no effects on IHD mortality, non-fatal MIs, or stroke. This clear effect on cardiovascular events was not lost on sensitivity analyses. The reduction in cardiovascular events was clearer in subgroups with greater baseline SFA intakes, greater reduction in SFA in the intervention group, and studies with greater serum total cholesterol and LDL cholesterol reductions. Meta-regression confirmed that degree of reduction in cardiovascular events was related to degree of reduction of serum total cholesterol, and there was a modest suggestion of greater protection with greater SFA reduction or greater increase in unsaturated FAs in the diet.

Palmitic acid (C16:0) is one of the important constituent acids of TG in adipose tissue. In this regard, palmitic acid content of blood has the greatest diagnostic and prognostic significance. It is considered that palmitic acid is linked with adverse cardiovascular events [27,28], and its high consumption raises the risk of CVD. The results of the randomized crossover investigation indicate that the palmitic acid-enriched diet resulted in increased fasting plasma LDL cholesterol, and HDL cholesterol concentrations [29]. It has been shown that after a decrease in the intake of SFA, blood concentrations of palmitic acid, LDL, and glucose diminish [30]. Results of a prospective study on US females and males [31] suggest that high blood levels of palmitic FA are associated with a high risk of the onset and progression of IHD. The prospective case-control study CIRCS [32], conducted by Japanese scientists, has yielded similar results. The LURIC study (the Ludwigshafen Risk and Cardiovascular Health study) [33] have investigated the link of SFA in the blood with overall and cardiovascular mortality among patients referred to coronary angiography. The results revealed that palmitic acid is related to a higher risk of death from CVD. Palmitic FA, by enhancing inflammation-related signaling of lipopolysaccharides in macrophages, promotes inflammation and the development of CVD [34-36]. In addition, inflammatory activity probably is characterized by increased production of pro-inflammatory cytokines and oxidants, leading to cellular hypertrophy and apoptosis. The findings show that elevated levels of palmitic acid and likely other SFAs can contribute significantly to cardiac damage [37].

Myristic acid (C14:0). In tissues of humans and animals, this acid is present at relatively low concentrations, on average, $1 \%$ of all FA by weight [38]. Although myristic acid is a minor plasma SFA, it has attracted growing attention because of clinical evidence suggesting its potent cholesterol-upregulating action [39]. Therefore, Fattore E. et al. [40] conducted a systematic meta-analysis, comprising a total of 51 studies with the participation of 1526 volunteers. The results of this meta-analysis show that the major dietary saturated fats (palmitic, stearic, lauric, and myristic acids) have differential effects on the lipid profile: Myristic and lauric acids increase all the cholesterol fractions (e.g., total cholesterol, LDL cholesterol, HDL cholesterol, LDL cholesterol/HDL cholesterol ratio, TG, apolipoprotein A-I, and apolipoprotein B) more than does palmitic acid, and palmitic acid increases all the cholesterol fractions more than does stearic acid. In a prospective case-control study known as CIRCS [32], blood levels of myristic acid were higher in patients with IHD than in a control group of subjects. Multivariate regression analysis uncovered a link of myristic FA with higher IHD risk.

Stearic acid (C18:0). In contrast to palmitic acid, which correlates with hypercholesterolemia (HC), it is considered that stearic SFA does not have a significant influence on lipid metabolism [41]. However, in the randomized investigations Meng H. et al. [29] and Mah E. et al. [42] the stearic acid-enriched diets 
resulted in lower fasting plasma LDL, HDL, and non-HDL-cholesterol concentrations. By contrast, in the randomized controlled trial Baer D. J. et al. [43] and in a study by Mensink R.P. et al. [10] consumption of stearic acid as an supplement did not affect the in blood lipids and any of the primary risk factors for cardiovascular disease. In general, the data on the influence of stearic acid on CVD are contradictory. For instance, in the prospective investigations [44,45], it has been demonstrated that high consumption of stearic acid does not correlate with a higher risk of IHD and MI. By contrast, in the prospective cohort study by Zong et al. [46] and in research Praagman et al. [47], stearic acid was found to make a major contribution to the development and course of IHD. Hunter et al. [48] have shown an independent relation of stearic FA with a higher risk of IHD, but this link turned out to be weak after normalization to the sum of other studied SFA (lauric, myristic, and palmitic acids). Harvey et al. [27] have reported that stearic acid induces apoptosis and necrosis of endothelial cells more strongly than does palmitic or myristic FA. Furthermore, those authors advanced a hypothesis that intracellular accumulation of stearic FA can be proinflammatory and lipotoxic.

Epidemiological research indicates that SFA, especially those containing 12-16 carbon atoms, have the greatest effect on the blood concentration of LDL cholesterol and therefore are often associated both with a higher risk of CVD and with the severity of atherosclerotic lesions in arteries [38,49-51]. Present dietary guidelines recommend keeping SFA intake at 8-10\% of total energy intake for the prevention of IHD and the reduction of SFA consumption and increase of PUFA consumption is the most efficient method for the normalization of the lipid value in the blood. A change in the proportions of the ingested-with-food FA that affect the ratio of HDL cholesterol to LDL cholesterol may be more important than the simple limiting of SFA, at least myristic and stearic ones, both of which influence the HDL cholesterol level [52].

Clinical trials offer conflicting conclusions regarding the role of SFA and the risk of IHD and its clinical complications. But growing number of studies indicate that the impact of SFA on the course and mortality rates of CVD, is not so much dependent on the overall amount of SFA in the human body but rather on their ratio to unsaturated FA. A recent Cochrane meta-analysis [13] showed moderate-quality evidence that replacing the energy from SFA with PUFA reduces the risk of CVD events and MI, but no effect on all-cause mortality or IHD mortality.

\section{Unsaturated Fatty Acids}

\subsection{Monounsaturated Fatty Acids (MUFA)}

The FA that has a pair of hydrogen atoms missing in the middle part, and the freed bonds are connected to double bond between carbon atoms are called monounsaturated FA (Table 2).

Table 2. The most common monounsaturated fatty acids.

\begin{tabular}{cccc}
\hline $\begin{array}{c}\text { The Notation of Fatty Acid } \\
\text { (Number of Carbon Atoms: } \\
\text { Number } \boldsymbol{\pi} \text { Bonds) }\end{array}$ & Trivial Name & Systematic Name (IUPAC) & Chemical Formula \\
\hline $12: 1$ & Lauroleic & CIS-9-dodecenoic & $\mathrm{CH}_{3}-\mathrm{CH}_{2}-\mathrm{CH}=\mathrm{CH}\left(\mathrm{CH}_{2}\right)_{7}-\mathrm{COOH}$ \\
\hline $14: 1$ & Myristoleic & CIS-9-tetradecenoic & $\mathrm{CH}_{3}-\left(\mathrm{CH}_{2}\right)_{3}-\mathrm{CH}=\mathrm{CH}\left(\mathrm{CH}_{2}\right)_{7}-\mathrm{COOH}$ \\
\hline $16: 1$ & Palmitoleic & CIS-9-hexadecenoic & $\mathrm{CH}_{3}-\left(\mathrm{CH}_{2}\right)_{5}-\mathrm{CH}=\mathrm{CH}-\left(\mathrm{CH}_{2}\right)_{7}-\mathrm{COOH}$ \\
\hline $18: 1$ & Oleic & CIS-9-octadecenoic & $\mathrm{CH}_{3}-\left(\mathrm{CH}_{2}\right)_{7}-\mathrm{CH}=\mathrm{CH}-\left(\mathrm{CH}_{2}\right)_{7}-\mathrm{COOH}$ \\
\hline \multirow{2}{*}{$18: 1$} & Petroselinic & CIS-6-octadecenoic & $\mathrm{CH}_{3}-\left(\mathrm{CH}_{2}\right)_{10}-\mathrm{CH}=\mathrm{CH}-\left(\mathrm{CH}_{2}\right)_{4}-\mathrm{COOH}$ \\
\hline \multirow{2}{*}{$20: 1$} & Vaccenic & CIS-11-octadecenoic & $\mathrm{CH}_{3}-\left(\mathrm{CH}_{2}\right)_{5}-\mathrm{CH}=\mathrm{CH}-\left(\mathrm{CH}_{2}\right)_{9}-\mathrm{COOH}$ \\
\hline \multirow{2}{*}{$22: 1$} & Gadoleic & CIS-9-eicosanoic & $\mathrm{CH}_{3}-\left(\mathrm{CH}_{2}\right)_{9}-\mathrm{CH}=\mathrm{CH}-\left(\mathrm{CH}_{2}\right)_{7}-\mathrm{COOH}$ \\
\cline { 2 - 4 } & Gondoic & CIS-11-eicosenoic & $\mathrm{CH}_{3}-\left(\mathrm{CH}_{2}\right)_{7}-\mathrm{CH}=\mathrm{CH}-\left(\mathrm{CH}_{2}\right)_{9}-\mathrm{COOH}$ \\
\hline $24: 1$ & Erucic & CIS-13-docosanoic & $\mathrm{CH}_{3}-\left(\mathrm{CH}_{2}\right)_{7}-\mathrm{CH}=\mathrm{CH}-\left(\mathrm{CH}_{2}\right)_{11}-\mathrm{COOH}$ \\
\hline & Cetoleinoic & CIS-11-docosanoic & $\mathrm{CH}_{3}-\left(\mathrm{CH}_{2}\right)_{5}-\mathrm{CH}=\mathrm{CH}{ }_{3}-\left(\mathrm{CH}_{2}\right)_{11}-\mathrm{COOH}$ \\
\hline & Nervonic & CIS-15-tetracosenoic & $\mathrm{CH}_{3}-\left(\mathrm{CH}_{2}\right)_{7}-\mathrm{CH}=\mathrm{CH}\left(\mathrm{CH}_{2}\right)_{13}-\mathrm{COOH}$ \\
\hline
\end{tabular}


Lately, there is growing interest in investigating the participation of MUFA in the development of CVD because prospective studies have yielded inconsistent results about the influence of MUFA on IHD risk. It is known that MUFA are involved in many physiological processes in the human body, including energy metabolism, lipid biosynthesis, the maintenance of membrane integrity, antioxidant reactions, apoptosis, and aging [53,54]. Among MUFA, palmitoleic (C16:1) and oleic (C18:1) acids are most important in terms of the functional role in the human body.

Palmitoleic acid (C16:1) is one of the main MUFA of the omega-7 ( $\omega-7)$ FA family. There is evidence that the $\mathrm{C} 16: 1$ acid is a major product of endogenous lipogenesis [55]. In the human body, the biosynthesis of cis-palmitoleic acid proceeds mainly in the liver and to a lesser extent in adipose tissue, where this FA is later incorporated into phospholipids, TG, waxes, and cholesterol esters [56].

Epidemiological studies suggest that palmitoleic FA participates in cholesterol metabolism and hemostasis, but its influence on the cardiovascular system is inconsistent. In some randomized controlled trials, consumption of capsules or diets rich in palmitoleic acid has been associated with lower blood concentrations of LDL cholesterol and TG and with substantial upregulation of HDL cholesterol [56,57]. Other studies have uncovered correlations between palmitoleic FA and such cardiovascular risk factors as hypertension; high blood levels of total cholesterol, TG, apolipoprotein A1, and apolipoprotein B; and endothelial dysfunction. Palmitoleic acid may behave as an SFA rather than a MUFA by increasing insulin resistance and heart rate and can affect the levels of total cholesterol and LDL cholesterol [58,59]. One research group [59] has found it intriguing that palmitoleic (C16:1) acid can raise the LDL cholesterol level more strongly than palmitic acid (C16:0). Chei et al. [32] have demonstrated that C16:1 acid content not only was higher in a group of patients with IHD than in a control group but also increased the risk of IHD. Overall, the discrepancies in the results may derive from differences in study populations. Nonetheless, most investigators tend to believe that for subjects with definite dyslipoproteinemias, palmitoleic acid as a nutritional supplement can be the main intervention for improving the blood lipid profile [60,61].

Oleic acid (C18:1) is the most prevalent MUFA in human food. It constitutes approximately half of FA content of TG in adipose tissue and has turned out to be the main acceptor of reactive oxygen species (ROS) in models of oxidative stress. The strongest oxidants for oleic FA are the superoxide anion-radical, nitrogen dioxide, and ozone [62]. When they act on the C18:1 acid, hydroxy derivatives [63] and/or short-chain SFA are formed. Research on oleic acid has revealed its influence on the cardiovascular system [64]. Oleic acid can improve the blood lipid profile [65], maintain healthy body weight [66], and even prevent palmitic-SFA-promoted mitochondrial dysfunction, insulin resistance, and inflammation-related signaling in neuronal cells [67] and skeletal muscle [68]. Nevertheless, the molecular mechanisms responsible for the protective effects of oleic acid against CVD are poorly studied.

Enrichment of LDL particles with oleic acid can shorten the stay of LDL particles in the artery wall and consequently may lower the risk of atherosclerosis [69]. Harvey et al. [70] propose that endothelial cells attempt to turn excessively taken up stearic acid into the more beneficial oleic acid. A positive correlation between blood levels of oleic acid and TG has been noted by Duarte et al. in patients with heart disease [71]. Those authors theorized that high levels of oleic acid can cause initial events of the atherosclerotic process. Delgado et al. [36] have discovered a direct link of oleic acid with markers of inflammation and with heart failure.

Thus, further research is needed on the impact of MUFA on IHD risk factors and clinical endpoints in order to elucidate a possible role of MUFA in primary and secondary prevention of IHD.

\subsection{Polyunsaturated Fatty Acids (PUFA)}

In Table 3 shows two main families: omega-3 $(\omega-3)$ and omega-6 ( $\omega-6)$ PUFA, depending on the position of the first double bond (if we count from the methyl end of the group). 
Table 3. The most physiologically important (common) polyunsaturated fatty acids.

\begin{tabular}{|c|c|c|c|}
\hline $\begin{array}{c}\text { The Notation of Fatty Acid } \\
\text { (Number of Carbon Atoms: } \\
\text { Number } \pi \text { Bonds) }\end{array}$ & Trivial Name & Systematic Name (IUPAC) & Chemical Formula \\
\hline \multicolumn{4}{|c|}{ Dienoic Acids } \\
\hline $18: 2(\omega-6)$ & Linoleic & 9,12-octadecadienoic & $\begin{array}{c}\mathrm{CH}_{3}-\left(\mathrm{CH}_{2}\right)_{4}-\mathrm{CH}=\mathrm{CH}-\mathrm{CH}_{2}-\mathrm{CH}= \\
\mathrm{CH}-\left(\mathrm{CH}_{2}\right)_{7}-\mathrm{COOH}\end{array}$ \\
\hline $20: 2(\omega-6)$ & Eicosadienoic & 11,14-eicosadienoic & $\begin{array}{c}\mathrm{CH}_{3}-\left(\mathrm{CH}_{2}\right)_{4}-\mathrm{CH}=\mathrm{CH}-\mathrm{CH}_{2}-\mathrm{CH}= \\
\mathrm{CH}-\left(\mathrm{CH}_{2}\right)_{9}-\mathrm{COOH}\end{array}$ \\
\hline \multicolumn{4}{|c|}{ Trienoic Acids } \\
\hline $18: 3(\omega-3)$ & $\alpha$-linolenic & $9,12,15$-octadecatrienoic & $\begin{array}{c}\mathrm{CH}_{3}-\mathrm{CH}_{2}-\mathrm{CH}=\mathrm{CH}-\mathrm{CH}_{2}-\mathrm{CH}= \\
\mathrm{CH}-\mathrm{CH}_{2}-\mathrm{CH}=\mathrm{CH}-\left(\mathrm{CH}_{2}\right)_{7}-\mathrm{COOH}\end{array}$ \\
\hline $18: 3(\omega-6)$ & $\gamma$-linolenic & $6,9,12$-octadecatrienoic & $\begin{array}{l}\mathrm{CH}_{3}-\left(\mathrm{CH}_{2}\right)_{4}-\mathrm{CH}=\mathrm{CH}-\mathrm{CH}_{2}-\mathrm{CH}= \\
\mathrm{CH}-\mathrm{CH}_{2}-\mathrm{CH}=\mathrm{CH}-\left(\mathrm{CH}_{2}\right)_{4}-\mathrm{COOH}\end{array}$ \\
\hline $20: 3(\omega-6)$ & Eicosatrienoic & Eicosatrienoic-5,8,11 & $\begin{array}{l}\mathrm{CH}_{3}-\left(\mathrm{CH}_{2}\right)_{7}-\mathrm{CH}=\mathrm{CH}-\mathrm{CH}_{2}-\mathrm{CH}= \\
\mathrm{CH}-\mathrm{CH}_{2}-\mathrm{CH}=\mathrm{CH}-\left(\mathrm{CH}_{2}\right)_{3}-\mathrm{COOH}\end{array}$ \\
\hline \multicolumn{4}{|c|}{ Tetraenoic Acids } \\
\hline $20: 4(\omega-6)$ & Arachidonic & 5,8,11,14-eicosatetraenoic & $\begin{array}{c}\mathrm{CH}_{3}-\left(\mathrm{CH}_{2}\right)_{4}-\mathrm{CH}=\mathrm{CH}-\mathrm{CH}_{2}-\mathrm{CH}= \\
\mathrm{CH}-\mathrm{CH}_{2}-\mathrm{CH}=\mathrm{CH}-\mathrm{CH}_{2}-\mathrm{CH}= \\
\mathrm{CH}-\left(\mathrm{CH}_{2}\right)_{3}-\mathrm{COOH}\end{array}$ \\
\hline \multicolumn{4}{|c|}{ Pentaenoic Acids } \\
\hline $20: 5(\omega-3)$ & Timnodonic & Eicosapentaenoic-5,8,11,14,17 & $\begin{array}{c}\mathrm{CH}_{3}-\mathrm{CH}_{2}-\mathrm{CH}=\mathrm{CH}-\mathrm{CH}_{2}-\mathrm{CH}= \\
\mathrm{CH}-\mathrm{CH}_{2}-\mathrm{CH}=\mathrm{CH}-\mathrm{CH}_{2}-\mathrm{CH}= \\
\mathrm{CH}-\mathrm{CH}_{2}-\mathrm{CH}=\mathrm{CH}-\left(\mathrm{CH}_{2}\right)_{3}-\mathrm{COOH}\end{array}$ \\
\hline $22: 5(\omega-3)$ & Clupanodonic & 7,10,13,16,19-docosapentaenoic & $\begin{array}{c}\mathrm{CH}_{3}-\mathrm{CH}_{2}-\mathrm{CH}=\mathrm{CH}-\mathrm{CH}_{2}-\mathrm{CH}= \\
\mathrm{CH}-\mathrm{CH}_{2}-\mathrm{CH}=\mathrm{CH}-\mathrm{CH}_{2}-\mathrm{CH}= \\
\mathrm{CH}-\mathrm{CH}_{2}-\mathrm{CH}=\mathrm{CH}-\left(\mathrm{CH}_{2}\right)_{5}-\mathrm{COOH}\end{array}$ \\
\hline \multicolumn{4}{|c|}{ Hexaenoic Acids } \\
\hline $22: 6(\omega-3)$ & Cervonic & Docosahexaenoic-4,7,10,13,16,19 & $\begin{array}{c}\mathrm{CH}_{3}-\mathrm{CH}_{2}-\mathrm{CH}=\mathrm{CH}-\mathrm{CH}_{2}-\mathrm{CH}= \\
\mathrm{CH}-\mathrm{CH}_{2}-\mathrm{CH}=\mathrm{CH}-\mathrm{CH}_{2}-\mathrm{CH}= \\
\mathrm{CH}-\mathrm{CH}_{2}-\mathrm{CH}=\mathrm{CH}-\mathrm{CH}_{2}-\mathrm{CH}= \\
\mathrm{CH}-\left(\mathrm{CH}_{2}\right)_{2}-\mathrm{COOH}\end{array}$ \\
\hline
\end{tabular}

\section{Omega-3 Polyunsaturated Fatty Acids}

Long-chain $\omega$-3 PUFA represent a special class of FA that contain multiple DB, with the last DB being located three carbons away from the methyl terminus of the chain [72]. Abundance of $\omega-3$ PUFA is good for health, e.g., for the treatment of neurological problems [73], symptomatic relief of inflammatory disorders [74], improvement of whole-body metabolism [75], and for reducing the risk of CVD [72].

In the last years, many investigations have focused on the effects of $\omega-3$ PUFA in the prevention and treatment on major cardiovascular events. A recent Cochrane meta-analysis, which included 79 randomized controlled trials involving over 112,000 people, suggests that long-chain omega-3 FA do not have important positive or negative effects on mortality or CVD events and that they have little or no effect on other measures of cardiovascular health in primary or secondary prevention [76]. There was a suggestion that long-chain omega-3 FA reduced IHD events. However, this was not maintained in sensitivity analyses because all evidence was of moderate GRADE quality [76].

Another meta-analysis was conducted of 10 long-term, randomized trials of $\omega-3$ FA as either primary or secondary prevention in a total of 78,000 participants. During the entire observation period of meta-analysis there was no evidence of significantly lower rates of IHD or major vascular events among the patients who had received $\omega-3$ FA than among those in the control groups [77].

The recommendations to increase $\omega-3$ PUFA intake are based on observational evidence, but the randomized trials of supplements have largely not shown cardiovascular benefit. 
In the randomized Studies ASCEND (A Study of Cardiovascular Events in Diabetes) [78] and VITAL (The VITamin D and OmegA-3 TriaL) [79] evaluated the efficacy and safety of daily supplementation with $\omega-3$ FA, as compared with placebo, in relation to the risk of serious vascular events. But the trials have not suggested any differences in the effects of $\omega-3$ FA supplementation in the endpoints of major cardiovascular events.

However, when considering each $\omega-3$ PUFA can observe its own patterns.

$\alpha$-Linolenic acid (ALA) (C18:3) belongs the family of essential $\omega$-3 PUFA and contains three DB at positions 9,12, and 15. ALA is an essential FA, an important part of a mixed diet, predominantly found in plant oils, such as flaxseed and rapeseed oils. The findings in a recent Cochrane meta-analysis, which included 79 randomized controlled trials, found that increasing ALA probably slightly reduces risk of IHD mortality and arrhythmia, and may slightly reduce risk of CVD events [76]. According to a meta-analysis by Pan et al. [80], consumption of ALA probably can benefit the cardiovascular system, and each $1 \mathrm{~g} /$ day increase in ALA intake is associated with a 10\% decline in the risk of death from IHD. In a double-blind, randomized controlled clinical trial by Bloedon et al. [81] it was found that higher consumption of flaxseed oil can short lived LDL-cholesterol lowering effect, lipoprotein(s) and HDL. The suppressive effect of ALA on blood levels of total cholesterol, LDL and TG concentrations has been demonstrated in a randomized controlled study where walnuts and fatty fish served as a food supplement [82]. There are significant inverse correlations between the blood concentration of ALA and intima-media thickness of the internal carotid artery and between the blood docosahexaenoic acid (DHA) level and intima-media thickness of the common carotid artery [83-85]. In a small crossover trial with participants who had their first MI, the average intima-media thickness of the carotid artery was also inversely related to ALA [86]. Lemaitre et al. [87] have stated that the risk of sudden cardiac arrest increases with increasing ALA levels. There is a need for more prospective studies for clarifying the link between ALA and diseases of the circulation system, but some authors believe that ALA has moderate protective effects on the cardiovascular system [88].

Eicosapentaenoic acid (EPA) (C20:5) is one of the main components of complex lipids and is an essential PUFA. The mechanism behind the influence of EPA on atherosclerosis development consists of effects on endothelial dysfunction and oxidative stress as well as increased synthesis of eicosanoids (which dilate blood vessels and reduce thrombogenesis and inflammation), alleviation of atherogenic dyslipoproteinemia, and other effects [89]. Results from the large prospective randomized clinical trial JELIS [90], showed that administration of EPA $1.8 \mathrm{~g} /$ day resulted in a 19\% reduction in cardiovascular events in statin-treated patients and a decrease in blood concentration of LDL by $25 \%$ after the treatment. Unstable angina pectoris and coronary phenomena were also significantly alleviated in the group of patients receiving EPA. The researchers concluded that EPA is a promising FA for the prevention of major coronary events, especially nonfatal ones, in patients with $\mathrm{HC}$.

At present, the best available evidence for a role of omega- 3 fatty acids in atherosclerotic cardiovascular disease risk reduction is REDUCE-IT (the Reduction of Cardiovascular Events with Icosapent Ethyl-Intervention Trial) [91]. The Icosapent ethyl is a highly purified and stable EPA ethyl ester. The results of REDUCE-IT provide evidence that the patients with elevated triglyceride levels who received $2 \mathrm{~g}$ of icosapent ethyl twice daily relative to risk of major ischemic events, including cardiovascular death, was significantly lower.

EPA is beneficial for endothelial function: In human umbilical vein endothelial cells (HUVECs), EPA improves the balance between nitric oxide and peroxynitrite and acts synergistically with statins [92]. EPA attenuates palmitic-acid-induced formation of ROS, expression of adhesion molecules and cytokines, activation of apoptosis-related proteins, and apoptosis of HUVECs [93,94]. In addition, EPA inhibits lipid peroxidation processes in membrane vesicles [95]. These antioxidant properties may be attributed to the incorporation of EPA into the lipid bilayer, where EPA can prevent the spread of ROS and preserve the structural organization of lipid membranes [96].

It has been hypothesized that EPA induces neovascularization involving human endothelial-cell progenitors, thereby preventing ischemic damage [97]. Because EPA has high lipophilicity, its possible 
therapeutic effects on the atherosclerotic plaque include anti-inflammatory and antioxidant activities, a reduction in monocyte adhesion to an endothelium, a decrease in the accumulation of macrophages and foam cells in lipid spots, and an increase in the thickness of the fibrotic cover on top of a lipid-rich plaque [89,98-100]. Zampelas [101] has determined that the proportion of EPA in phospholipids of stable plaques inversely correlates with inflammation of the plaques and the number of T-cells there. EPA diminishes intima-media thickness of the carotid artery in patients with hypertriglyceridemia and patients with risk factors of atherosclerosis, despite treatment of the main diseases [102,103]. There are data on the ability of EPA to resolve an inflammatory process via the synthesis of resolvins and special proteins [104,105]. Both substances reduce the recruitment of neutrophils from the blood, thus helping to resolve blood vessel inflammatory processes seen in atherosclerosis [106]. Incorporation of EPA into the membranes of platelets may reduce their aggregation, and in case of a rupture of an atherosclerotic plaque that leads to acute coronary syndrome, EPA may help to limit the size of the adjacent clot by diminishing platelet aggregation, thereby minimizing MI volume [89]. Additionally, EPA not only improves the blood lipid profile but also helps to lower the levels of vascular inflammatory biomarkers, thereby inhibiting the development of clinically important cardiovascular events. The use of EPA as an adjunctive therapy helps to lower the risk of CVD [107].

Docosahexaenoic acid (DHA) (C22:6) has unique stereochemical structure, features the highest unsaturatedness, ensures effective signal conductance in neurons thereby preventing spasms of the heart and blood vessels [108], and can have antithrombotic, antiatherogenic, antiarrhythmic, and vasoprotective actions.

Qi et al. [109] have shown that DHA lowers blood TG levels by reducing the activity of liver enzymes. Simultaneously, there was an increase in blood HDL levels, through enhanced synthesis of phospholipids. Honda et al. [110] and Wang et al. [111] have demonstrated that DHA lowers such inflammation markers as interleukin 1- $\beta$, tumor necrosis factor $\alpha$ (TNF- $\alpha$ ), and interleukin 6 . There is evidence that the blood level of DHA is linked with the endothelial function in patients with IHD. These results imply that that a low DHA concentration may be a biomarker of endothelial dysfunction [112]. Fahs et al. have presented proof that DHA can alleviate the endothelial-function aberrations that are caused by a high-fat diet [113].

Some studies address the question which $\omega-3$ PUFA has the strongest influence on the blood lipid profile. Both EPA and DHA effectively diminish the level of TG but differently affect the levels of HDL and LDL cholesterol [114,115]. Besides, concentrations of circulating DHA and EPA are inversely proportional to the prevalence of CVD [116].

Docosapentaenoic acid (DPA) (C22:5) is a PUFA of the $\omega-3$ class and is an intermediate product between EPA and DHA [117]. In food sources, the DPA amount is too low. DPA is a precursor of a large class of lipid mediators (special proteins, resolvins, maresins, and isoprostanes) mainly taking part in the elimination of inflammation, with specific effects in contrast to other $\omega-3$ PUFAs. The DPA is beneficial for the cardiovascular system and correlates with risk markers of metabolic diseases, especially with parameters of blood lipids, with platelet aggregation, and with insulin sensitivity [118].

Japanese researchers [119] have documented a significant correlation between nutritional DPA supplementation and lower prevalence of CVD. This finding has been confirmed in a control study with a six-year observation period, which also indicates that the link between DPA and CVD does not depend on other $\omega-3$ FA.

Recent research further clarified which pathophysiological mechanisms of action of DPA may target CVD. A prospective cohort study suggests that the total concentration of $\omega-3$ FA is associated with lower prevalence of congestive heart failure, with DPA lowering this parameter to $40 \%$ of the control level [120]. In another study, researchers investigated the impact of $\omega-3$ PUFA on instability of the atherosclerotic plaque in a coronary artery [121]; low blood concentrations of DPA significantly correlated with plaques enriched with lipids. Those authors supposed that downregulation of DPA may promote the frequency of unstable plaque formation leading to the development of acute coronary syndrome and MI [121]. 
It is known that platelet aggregation is an early event in the development of thrombosis and is initiated by thromboxane A2. The EPA, DPA, and DHA attenuate the platelet aggregation stimulated by collagenic or arachidonic acid (ARA), depending on the dose. The DPA was found to be an almost tenfold more potent inhibitor than EPA. Further research on human whole blood has confirmed these data [122,123]. The absence of EPA, DPA, or DHA in the circulation may be an independent predictor and risk marker of CVD [124].

The Omega-3 Index may be the marker of choice for the 21st century because fulfills many of the criteria of a CVD risk factors [125]. Tribulova N. et al. [125] have studied the most Recent Data on the Omega-3 Index. Taken together, it appears that the omega-3 index may be a good candidate as a biomarker for assessing the risk of cardiac undesirable events. However, available data suggest that the anti-arrhythmic window for circulating $\omega-3$ PUFAs is narrow. Thus, relatively high levels of free $\omega$-3 PUFAs (e.g., due to infusion) may not always be associated with protection of the acutely injured heart. Nevertheless, monitoring of both the omega-3 index and plasma levels may reflect the actual status of the $\omega-3$ PUFAs that should always be considered with respect to their effects.

\section{Omega-6 Polyunsaturated Fatty Acids}

These PUFA are less studied than $\omega$-3 FA. Although most articles suggest that PUFA are overall effective against risk factors of CVD such as dyslipoproteinemias, hypertension, and atherosclerosis. It is feared that high levels of $\omega-6$ PUFA compared to $\omega-3$ PUFA may worsen cardiovascular risk by increasing inflammation. Therefore it is still debated whether the activities of $\omega-6$ PUFA are pro- or anti-inflammatory. Some investigators have reported antagonistic effects of PUFA: Although $\omega-3$ FA manifest themselves as cardioprotectors, $\omega-6$ PUFA exert pro-inflammatory properties [126-128].

However, this view is now enjoys little to no direct support from studies in humans. In a recent Cochrane meta-analysis, which included 19 randomized controlled trials and 6461 participants, compared higher and lower omega intake-6 FA in adults with or without CVD, effects were evaluated for at least 12 months [129]. Authors found that increasing $\omega-6$ PUFA may reduce risk of MI. Although the benefits of $\omega-6$ PUFA remain unproven, increasing their intake may benefit people at high risk of developing MI. It has been shown that increasing $\omega-6$ PUFA reduces serum total cholesterol over at least one year, but not other lipid fractions in the blood. In addition, in recent years, the complex biochemistry of the eicosanoids (and docosanoids and octadecanoids) has become clearer, so the class itself $\omega-6$ PUFA can no longer be so simply regarded as pro-inflammatory [130].

These new findings began to erode the view that PUFA biology could be summed up in one simple the omega-6/omega-3 ratio. For ensuring the body has the proper level of $\omega-3$ FA reactions and the possibility of good health, changes in the participation of $\omega-3$ and $\omega-6$ FAs in the Daily Nutritional Ration are important. According to the Polish Forum of Cardiovascular Disease Prophylactic Program, the proportion of $\omega-6$ to $\omega-3$ acids should be 4:1 [131]. Nevertheless, in the literature more and more often you can find a ratio of 10:1 and higher. Both the shortage and over-use of FA may be harmful to the human body. Therefore, we can assume that a higher inflammatory status can be seen in settings where the omega-6/omega-3 ratio are high, but the problem is not a large content of $\omega-6$ FA, but rather the absence of $\omega-3$ FA.

Linoleic acid (LA) (C18:2) is the most prevalent FA in phospholipids, in particular in cardiolipins. It constitutes $\sim 10 \%$ of FA content of adipose tissue and more than $20 \%$ of all FA in human blood. LA is not synthesized in the mammalian (human) body. Substantial amounts are present in plant oils. Half of all cholesterol esters in the blood are formed from LA.

The main role of LA in the body (animals and humans) is a biochemical precursor of physiologically important long-chain PUFA, such as ARA, with subsequent synthesis of proinflammatory eicosanoids (prostaglandin E2), leukotriene B4, and thromboxane A4 [132-134]. Higher production of proinflammatory eicosanoids may lead to the emergence of other biomarkers of inflammation (e.g., interleukin 6, TNF- $\alpha$, and C-reactive protein), which are linked with a higher risk of CVD. A high consumption of LA may cause the increased of ALA and total amounts of $\omega-3$ EPA and DHA actually 
increased slightly [135]. On the other hand, consumption of LA as a nutritional supplement does not affect the concentrations of various circulating inflammatory biomarkers [136,137]. In addition, a number of clinical studies have been conducted that addressed the link between LA consumption and inflammation. For example, Ferrucci et al. [138] have noted that total concentrations of $\omega-6$ PUFA in the blood are inversely proportional to blood concentrations of C-reactive protein and interleukins -1 and -6 , and to the TNF- $\alpha$ level. According to Choo et al. [139], LA blood concentration inversely correlates with the size of very-LDL and LDL particles and directly correlates with HDL particle size. Available evidence from randomized controlled trials shows that replacement of saturated fat with linoleic acid effectively lowers serum cholesterol but does not support the hypothesis that this translates to a lower risk of death from coronary heart disease or all causes [140]. In a meta-analysis of 22 studies, including prospective cohort studies and case-control studies, concentrations of LA in the blood and tissue were found to inversely correlate with nonfatal endpoints of IHD [141].

$\gamma$-Linolenic acid (GLA) (C18:3) is a PUFA whose chain is composed of 18 carbon atoms and three DB at positions 6, 9, and 12. The GLA is found in oils from various seeds but is usually taken as a nutritional supplement [142]. The GLA can stimulate the production of eicosanoids (in particular prostaglandin E2), exerts anti-inflammatory and anti-proliferative effects, and can lower the levels of lipids [143]. A possible indication for nutritional supplementation with GLA is a confirmed lower GLA content of phospholipids and of cholesterol esters in the blood of patients with hypertriglyceridemia or HC [144]. In a study by Schwab et al. [145] on people taking GLA as a nutritional supplement, there was a significant decrease in blood concentrations of TG, total cholesterol, and LDL, with upregulation of the HDL fraction.

Data regarding the influence of GLA on adverse cardiovascular events and mortality rates of CVD are virtually nonexistent. Das et al. [146] have found that GLA benefits blood vessels by preventing arterial hypertension and helps to prevent IHD complications by means of the blood-clotting system.

Arachidonic acid (ARA) (C20:4) is a 20-carbon compound with four DB at positions 5, 8, 11, and 14. The ARA is component of phospholipids, TG, and cholesterol esters. It constitutes $2 \%$ to $8 \%$ of the total amount of FA. Endogenous production of ARA mainly occurs because of its liberation from phospholipids of the cellular membrane. This process is catalyzed by enzymes of the phospholipase A2 superfamily [147]. Given that human food contains large amounts of LA, the amount of ARA almost always exceeds the level necessary for the maintenance of the balance among PUFA [148]. It is believed that ARA is a precursor of prostaglandins and many other eicosanoids [149], imparts flexibility and fluidity to cellular membranes, serves as a lipid secondary messenger in cellular signaling, acts as an inflammatory mediator, and causes vasodilatation [150]. Furthermore, ARA influences the activity of the cardiac proton pumps that make the main contribution to cardiomyocyte excitability.

The ARA can induce oxidative stress [151], which is an important factor of atherosclerosis pathogenesis [152]. A higher blood level of ARA is related to higher prevalence of arterial hypertension [153]. The research into the risk of atherosclerosis has revealed that lower LA levels and higher blood levels of ARA correspond to a higher risk of hypertension; moreover, ARA levels directly correlated with the body mass index and related metabolic syndrome [154-156].

On the whole, for atherosclerosis prophylaxis, the most important PUFA are essential FA of the $\omega-6$ family. Their hypocholesterolemic activity is attributed primarily to a decrease in the concentration of LDL cholesterol and in the blood level of SFA as well as upregulation of LA, which undergoes oxidation more slowly than ARA does.

Finally, we summarized the data and presented it in summary Table 4 that reports positive and negative effects of different FA family on the cardiovascular system. 
Table 4. The influence of fatty acids on the cardiovascular system.

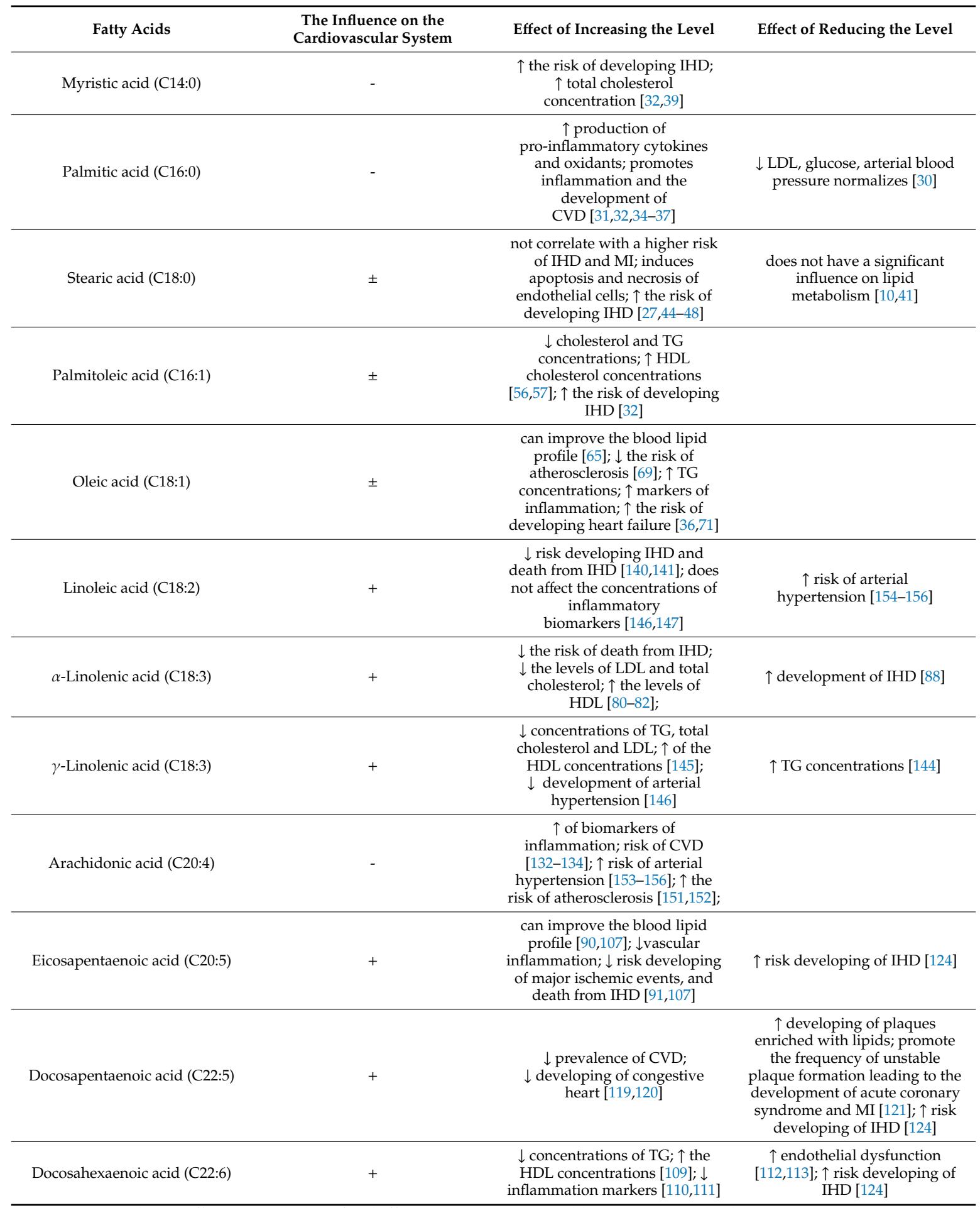

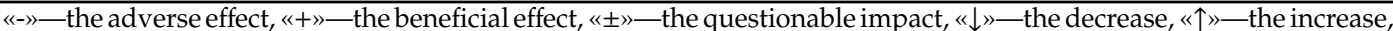
IHD—ischemic heart disease, CVD—cardiovascular disease, LDL—low-density lipoproteins, HDL—high-density lipoprotein cholesterol, MI—myocardial infarction, TG—triglyceride.

\section{Conclusions}

Consequently, the research into the influence of individual FA on the etiopathogenesis, diagnosis, prevention, risk assessment, and treatment of CVD is a promising rapidly developing field of biomedicine. The possible contradictions between experimental and clinical results depend on different concentrations of the studied drugs, their composition, sample size, and duration of observation. 
However, data on associations of various SFA and unsaturated FA with lipid-lipoprotein parameters and with inflammatory and oxidative markers of CVD are also intriguing and prompting more and more studies for clarification and elaboration of already known mechanisms underlying the influence of FA on the cardiovascular system.

Author Contributions: V.S.S.: conceptualization, writing-original draft preparation, funding acquisition; Y.V.P.: conceptualization, writing - original draft preparation; E.V.K.: writing—original draft preparation, data curation, revising it critically for important intellectual content; E.M.S.: writing—review and editing, supervision; Y.I.R.: writing-review and editing, data curation, project administration, final approval of the manuscript to be published. All authors have read and agreed to the published version of the manuscript.

Funding: This review was conducted out within the framework of RFBR project №19-315-90013, and as part of the budget theme on the state task No. AAAA-A17-117112850280-2.

Acknowledgments: The English language was corrected and certified by shevchuk-editing.com.

Conflicts of Interest: The authors declare that they have no conflicts of interest associated with publication of this review.

\section{References}

1. WHO Mortality Database. Available online: http://www.who.int/healthinfo/mortality_data/en/ (accessed on 25 May 2016).

2. Townsend, N.; Wilson, L.; Bhatnagar, P.; Wickramasinghe, K.; Rayner, M.; Nichols, M. Cardiovascular disease in Europe: Epidemiological update 2016. Eur. Heart. J. 2016, 37, 3232-3245. [CrossRef] [PubMed]

3. Bäck, M. Omega-3 fatty acids in atherosclerosis and coronary artery disease. Futur. Sci. OA 2017, 3, 1-7. [CrossRef] [PubMed]

4. Siasos, G.; Tousoulis, D.; Oikonomou, E.; Zaromitidou, M.; Verveniotis, A.; Plastiras, A.; Kioufis, S.; Maniatis, K.; Miliou, A.; Siasou, Z.; et al. Effects of omega-3 fatty acids on endothelial function, arterial wall properties, inflammatory and fibrinolytic status in smokers: A cross over study. Int. J. Cardiol. 2013, 166, 340-346. [CrossRef] [PubMed]

5. Oh, P.C.; Koh, K.K.; Sakuma, I.; Lim, S.; Lee, Y.; Lee, S.; Lee, K.; Han, S.H.; Shin, E.K. Omega-3 fatty acid therapy dose-dependently and significantly decreased triglycerides and improved flow-mediated dilation, however, did not significantly improve insulin sensitivity in patients with hypertriglyceridemia. Int. J. Cardiol. 2014, 176, 696-702. [CrossRef]

6. Hamazaki, K.; Iso, H.; Eshak, E.S.; Ikehara, S.; Ikeda, A.; Iwasaki, M.; Hamazaki, T.; Tsugane, S.; Tsugane, S.; Sawada, N.; et al. Plasma levels of n-3 fatty acids and risk of coronary heart disease among Japanese: The Japan Public Health Center-based (JPHC) study. Atherosclerosis 2018, 272, 226-232. [CrossRef]

7. Chen, X.; Liu, L.; Palacios, G.; Gao, J.; Zhang, N.; Li, G.; Lu, J.; Song, T.; Zhang, Y.; Lv, H. Plasma metabolomics reveals biomarkers of the atherosclerosis. J. Sep. Sci. 2010, 33, 2776-2783. [CrossRef] [PubMed]

8. Skeaff, C.M.; Miller, J. Dietary Fat and Coronary Heart Disease: Summary of Evidence from Prospective Cohort and Randomised Controlled Trials. Ann. Nutr. Metab. 2009, 55, 173-201. [CrossRef]

9. Eckel, R.H.; Jakicic, J.M.; Ard, J.D.; De Jesus, J.M.; Hubbard, V.S.; Lee, I.-M.; Lichtenstein, A.H.; Loria, C.M.; Millen, B.E.; Nonas, C.A.; et al. 2013 AHA/ACC Guideline on Lifestyle Management to Reduce Cardiovascular Risk: A Report of the American College of Cardiology/American Heart Association Task Force on Practice Guidelines. Circulation 2013, 129, 129-175. [CrossRef]

10. Mensink, R.P. Effects of Saturated Fatty Acids on Serum Lipids and Lipoproteins: A Systematic Review and Regression Analysis; World Health Organization: Geneva, Switzerland, 2016; 72p.

11. Benes, L.B.; Bassi, N.S.; Davidson, M.H. Omega-3 carboxylic acids monotherapy and combination with statins in the management of dyslipidemia. Vasc. Health Risk Manag. 2016, 12, 481-490. [CrossRef]

12. Mozaffarian, D.; Micha, R.; Wallace, S. Effects on Coronary Heart Disease of Increasing Polyunsaturated Fat in Place of Saturated Fat: A Systematic Review and Meta-Analysis of Randomized Controlled Trials. PLoS Med. 2010, 7, 1-8. [CrossRef]

13. Hooper, C.L.; Martin, N.; Abdelhamid, A.; Smith, G.D. Reduction in saturated fat intake for cardiovascular disease. Cochrane Database Syst. Rev. 2015, 6, 1-171. [CrossRef] [PubMed]

14. Pietinen, P.; Nissinen, A.; Vartiainen, E.; Tuomilehto, A.; Uusitalo, U.; Ketola, A.; Moisio, S.; Puska, P. Dietary changes in the North Karelia Project (1972-1982). Prev. Med. 1988, 17, 183-193. [CrossRef] 
15. Macri, E.V.; Lifshitz, F.; Alsina, E.; Juiz, N.; Zago, V.; Lezon, C.; Rodriguez, P.N.; Schreier, L.; Boyer, P.M.; Friedman, S.M. Monounsaturated fatty acids-rich diets in hypercholesterolemic-growing rats. Int. J. Food Sci. Nutr. 2015, 66, 400-408. [CrossRef]

16. Alsina, E.; Macri, E.V.; Lifshitz, F.; Bozzini, C.; Rodriguez, P.N.; Boyer, P.M.; Friedman, S.M. Efficacy of phytosterols and fish-oil supplemented high-oleic-sunflower oil rich diets in hypercholesterolemic growing rats. Int. J. Food Sci. Nutr. 2016, 67, 441-453. [CrossRef]

17. Covas, M.-I.; De La Torre, R.; Fitó, M. Virgin olive oil: A key food for cardiovascular risk protection. Br. J. Nutr. 2015, 113, 19-28. [CrossRef] [PubMed]

18. Keys, A. Seven Countries: A Multivariate Analysis of Death and Coronary Heart Disease; Harvard University Press: Cambridge, MA, USA, 1980.

19. Farvid, M.S.; Ding, M.; Pan, A.; Sun, Q.; Chiuve, S.E.; Steffen, L.M.; Willett, W.C.; Hu, F.B. Dietary Linoleic Acid and Risk of Coronary Heart Disease: A Systematic Review and Meta-Analysis of Prospective Cohort Studies. Circulation 2014, 130, 1568-1578. [CrossRef] [PubMed]

20. McGuire, S. Scientific Report of the 2015 Dietary Guidelines Advisory Committee. Washington, DC: US Departments of Agriculture and Health and Human Services, 2015. Adv. Nutr. 2016, 7, 202-204. [CrossRef] [PubMed]

21. Fritz, K.S.; Petersen, D.R. An overview of the chemistry and biology of reactive aldehydes. Free. Radic. Boil. Med. 2012, 59, 85-91. [CrossRef]

22. Brown, H.A.; Marnett, L.J. Introduction to Lipid Biochemistry, Metabolism, and Signaling. Chem. Rev. 2011, 111, 5817-5820. [CrossRef]

23. Wang, Z.; Li, S.; Cao, Y.; Tian, X.; Zeng, R.; Liao, D.F.; Cao, D. Oxidative Stress and Carbonyl Lesions in Ulcerative Colitis and Associated Colorectal Cancer. Oxidative Med. Cell. Longev. 2015, 2016, 1-15. [CrossRef]

24. Surekha, R.H.; Srikanth, B.B.M.V.; Jharna, P.; Ramachandra, R.V.; Dayasagar, R.V.; Jyothy, A. Oxidative stress and total antioxidant status in myocardial infarction. Singap. Med. J. 2007, 48, 137-142.

25. Bubnova, M.G. Diet, atherogenic hyperlipidemia and statins. J. CardioSomatics 2011, 2, 81-89.

26. Chiu, S.; Williams, P.T.; Krauss, R.M. Effects of a very high saturated fat diet on LDL particles in adults with atherogenic dyslipidemia: A randomized controlled trial. PLoS ONE 2017, 12, e0170664. [CrossRef] [PubMed]

27. Harvey, K.A.; Walker, C.L.; Pavlina, T.M.; Xu, Z.; Zaloga, G.P.; Siddiqui, R.A. Long-chain saturated fatty acids induce pro-inflammatory responses and impact endothelial cell growth. Clin. Nutr. 2010, 29, 492-500. [CrossRef] [PubMed]

28. Shen, H.; Eguchi, K.; Kono, N.; Fujiu, K.; Matsumoto, S.; Shibata, M.; Oishi-Tanaka, Y.; Komuro, I.; Arai, H.; Nagai, R.; et al. Saturated Fatty Acid Palmitate Aggravates Neointima Formation by Promoting Smooth Muscle Phenotypic Modulation Significance. Arter. Thromb. Vasc. Boil. 2013, 33, 2596-2607. [CrossRef]

29. Meng, H.; Matthan, N.R.; Wu, D.; Li, L.; Rodríguez-Morató, J.; Cohen, R.; Galluccio, J.M.; Dolnikowski, G.G.; Lichtenstein, A.H. Comparison of diets enriched in stearic, oleic, and palmitic acids on inflammation, immune response, cardiometabolic risk factors, and fecal bile acid concentrations in mildly hypercholesterolemic postmenopausal women-Randomized crossover trial. Am. J. Clin. Nutr. 2019, 110, 305-315. [CrossRef]

30. Ebbesson, S.O.; Tejero, M.E.; López-Alvarenga, J.C.; Harris, W.S.; Ebbesson, L.O.; Devereux, R.B.; Maccluer, J.W.; Wenger, C.; Laston, S.; Fabsitz, R.R.; et al. Individual saturated fatty acids are associated with different components of insulin resistance and glucose metabolism: The GOCADAN study. Int. J. Circumpolar Health 2010, 69, 344-351. [CrossRef]

31. Li, Y.; Hruby, A.; Bernstein, A.M.; Ley, S.H.; Wang, D.D.; Chiuve, S.E.; Sampson, L.; Rexrode, K.M.; Rimm, E.B.; Willett, W.C.; et al. Saturated Fats Compared With Unsaturated Fats and Sources of Carbohydrates in Relation to Risk of Coronary Heart Disease: A Prospective Cohort Study. J. Am. Coll. Cardiol. 2015, 66, 1538-1548. [CrossRef]

32. Chei, C.L.; Yamagishi, K.; Kitamura, A.; Kiyama, M.; Sankai, T.; Okada, T.; Imano, H.; Ohira, T.; Cui, R.; Umesawa, M.; et al. Serum Fatty Acid and Risk of Coronary Artery Disease-Circulatory Risk in Communities Study (CIRCS). Circ. J. 2018, 82, 3013-3020. [CrossRef]

33. Kleber, M.E.; Delgado, G.; Dawczynski, C.; Lorkowski, S.; März, W.; Von Schacky, C. Saturated fatty acids and mortality in patients referred for coronary angiography-The Ludwigshafen Risk and Cardiovascular Health study. J. Clin. Lipidol. 2018, 12, 455-463. [CrossRef] 
34. Jin, J.; Lu, Z.; Li, Y.; Cowart, L.A.; Lopes-Virella, M.F.; Huang, Y. Docosahexaenoic acid antagonizes the boosting effect of palmitic acid on LPS inflammatory signaling by inhibiting gene transcription and ceramide synthesis. PLoS ONE 2018, 13, e0193343. [CrossRef] [PubMed]

35. Hellmann, J.; Zhang, M.J.; Tang, Y.; Rane, M.; Bhatnagar, A.; Spite, M. Increased saturated fatty acids in obesity alter resolution of inflammation in part by stimulating prostaglandin production. J. Immunol. 2013, 191, 1383-1392. [CrossRef] [PubMed]

36. Delgado, G.E.; Krämer, B.K.; Lorkowski, S.; März, W.; Von Schacky, C.; Kleber, M.E. Individual omega-9 monounsaturated fatty acids and mortality-The Ludwigshafen Risk and Cardiovascular Health Study. J. Clin. Lipidol. 2017, 11, 126-135. [CrossRef] [PubMed]

37. Wang, Y.; Qian, Y.; Fang, Q.; Zhong, P.; Li, W.; Wang, L.; Fu, W.; Zhang, Y.; Xu, Z.; Li, X.; et al. Saturated palmitic acid induces myocardial inflammatory injuries through direct binding to TLR4 accessory protein MD2. Nat. Commun. 2017, 8, 13997-14010. [CrossRef]

38. Beauchamp, E.; Rioux, V.; Legrand, P. Acide myristique: Nouvelles fonctions de régulation et de signalisation. Med. Sci. 2009, 25, 57-63. [CrossRef]

39. Bradbury, K.E.; Skeaff, C.M.; Green, T.J.; Gray, A.R.; Crowe, F.L. The serum fatty acids myristic acid and linoleic acid are better predictors of serum cholesterol concentrations when measured as molecular percentages rather than as absolute concentrations. Am. J. Clin. Nutr. 2009, 91, 398-405. [CrossRef]

40. Fattore, E.; Bosetti, C.; Brighenti, F.; Agostoni, C.; Fattore, G. Palm oil and blood lipid-related markers of cardiovascular disease: A systematic review and meta-analysis of dietary intervention trials. Am. J. Clin. Nutr. 2014, 99, 1331-1350. [CrossRef]

41. Flock, M.R.; Kris-Etherton, P.M. Diverse physiological effects of long-chain saturated fatty acids. Curr. Opin. Clin. Nutr. Metab. Care 2013, 16, 133-140. [CrossRef]

42. Mah, E.A.; Schulz, J.; Kaden, V.N.; Lawless, A.L.; Rotor, J.; Mantilla, L.B.; Liska, D.J. Cashew consumption reduces total and LDL cholesterol: A randomized, crossover, controlled-feeding trial. Am. J. Clin. Nutr. 2017, 105, 1070-1078. [CrossRef]

43. Baer, D.J.; Novotny, J.A. Consumption of cashew nuts does not influence blood lipids or other markers of cardiovascular disease in humans: A randomized controlled trial. Am. J. Clin. Nutr. 2019, 109, 269-275. [CrossRef]

44. Praagman, J.; De Jonge, E.A.; Jong, J.C.K.-D.; Beulens, J.W.; Sluijs, I.; Schoufour, J.D.; Hofman, A.; Van Der Schouw, Y.T.; Franco, O.H. Dietary Saturated Fatty Acids and Coronary Heart Disease Risk in a Dutch Middle-Aged and Elderly Population. Arter. Thromb. Vasc. Boil. 2016, 36, 2011-2018. [CrossRef] [PubMed]

45. Praagman, J.; Beulens, J.W.; Alssema, M.; Zock, P.L.; Wanders, A.J.; Sluijs, I.; Van Der Schouw, Y. The association between dietary saturated fatty acids and ischemic heart disease depends on the type and source of fatty acid in the European Prospective Investigation into Cancer and Nutrition-Netherlands cohort1,2. Am. J. Clin. Nutr. 2016, 103, 356-365. [CrossRef] [PubMed]

46. Zong, G.; Li, Y.; Wanders, A.J.; Alssema, M.; Zock, P.L.; Willett, W.C.; Hu, F.B.; Sun, Q. Intake of individual saturated fatty acids and risk of coronary heart disease in US men and women: Two prospective longitudinal cohort studies. BMJ 2016, 355, 5796. [CrossRef] [PubMed]

47. Praagman, J.; Vissers, L.E.; Mulligan, A.A.; Laursen, A.S.D.; Beulens, J.W.; Van Der Schouw, Y.T.; Wareham, N.J.; Hansen, C.P.; Khaw, K.T.; Jakobsen, M.U.; et al. Consumption of individual saturated fatty acids and the risk of myocardial infarction in a UK and a Danish cohort. Int. J. Cardiol. 2018, 279, 18-26. [CrossRef]

48. Hunter, J.E.; Zhang, J.; Kris-Etherton, P.M. Cardiovascular disease risk of dietary stearic acid compared with trans, other saturated, and unsaturated fatty acids: A systematic review. Am. J. Clin. Nutr. 2009, 91, 46-63. [CrossRef]

49. Mensink, R.P.; Zock, P.L.; Kester, A.D.M.; Katan, M.B. Effects of dietary fatty acids and carbohydrates on the ratio of serum total to HDL cholesterol and on serum lipids and apolipoproteins: A meta-analysis of 60 controlled trials. Am. J. Clin. Nutr. 2003, 77, 1146-1155. [CrossRef]

50. PREDIMED Study Investigators; Guasch-Ferré, M.; Babio, N.; Martinez-Gonzalez, M.A.; Corella, D.; Ros, E.; Martín-Peláez, S.; Estruch, R.; Arós, F.; Gómez-Gracia, E.; et al. Dietary fat intake and risk of cardiovascular disease and all-cause mortality in a population at high risk of cardiovascular disease. Am. J. Clin. Nutr. 2015, 102, 1563-1573. [CrossRef] 
51. Zhuang, P.; Zhang, Y.; He, W.; Chen, X.; Chen, J.; He, L.; Mao, L.; Wu, F.; Jiao, J. Dietary Fats in Relation to Total and Cause-Specific Mortality in a Prospective Cohort of 521120 Individuals With 16 Years of Follow-up. Circ. Res. 2019, 124, 757-768. [CrossRef]

52. Müller, H.; Lindman, A.S.; Brantsæter, A.-L.; Pedersen, J.I. The Serum LDL/HDL Cholesterol Ratio Is Influenced More Favorably by Exchanging Saturated with Unsaturated Fat Than by Reducing Saturated Fat in the Diet of Women. J. Nutr. 2003, 133, 78-83. [CrossRef]

53. Abel, S.; Schuhr, I.; Gelderblom, W.A. The Antioxidant Potential of Oleic Acid and Effect on Cell Survival in Carcinogenesis; ISSFAL: Maastricht, The Netherlands, 2010; 141p.

54. Schwingshackl, L.; Strasser, B.; Hoffmann, G. Effects of Monounsaturated Fatty Acids on Cardiovascular Risk Factors: A Systematic Review and Meta-Analysis. Ann. Nutr. Metab. 2011, 59, 176-186. [CrossRef]

55. Okada, T.; Furuhashi, N.; Kuromori, Y.; Miyashita, M.; Iwata, F.; Harada, K. Plasma palmitoleic acid content and obesity in children. Am. J. Clin. Nutr. 2005, 82, 747-750. [CrossRef] [PubMed]

56. Frigolet, M.E.; Gutiérrez-Aguilar, R. The Role of the Novel Lipokine Palmitoleic Acid in Health and Disease. Adv. Nutr. 2017, 8, 173-181. [CrossRef]

57. Mozaffarian, D.; Cao, H.; King, I.B.; Lemaitre, R.N.; Song, X.; Siscovick, D.S.; Hotamisligil, G.S. Circulating palmitoleic acid and risk of metabolic abnormalities and new-onset diabetes. Am. J. Clin. Nutr. 2010, 92, 1350-1358. [CrossRef] [PubMed]

58. Delarue, J.; Magnan, C. Free fatty acids and insulin resistance. Curr. Opin. Clin. Nutr. Metab. Care 2007, 10, 142-148. [CrossRef] [PubMed]

59. Ebbesson, S.O.; Lopez-Alvarenga, J.C.; Okin, P.M.; Devereux, R.B.; Tejero, M.E.; Harris, W.S.; Ebbesson, L.O.; Maccluer, J.W.; Wenger, C.; Laston, S.; et al. Heart rate is associated with markers of fatty acid desaturation: The GOCADAN study. Int. J. Circumpolar Health 2012, 71, 17343-17350. [CrossRef]

60. Ebbesson, S.O.; Voruganti, V.S.; Higgins, P.B.; Fabsitz, R.R.; Ebbesson, L.O.; Laston, S.; Harris, W.S.; Kennish, J.; Umans, B.D.; Wang, H.; et al. Fatty acids linked to cardiovascular mortality are associated with risk factors. Int. J. Circumpolar Health 2015, 74, 28055-28067. [CrossRef]

61. Bernstein, A.M.; Roizen, M.F.; Martinez, L. Purified palmitoleic acid for the reduction of high-sensitivity C-reactive protein and serum lipids: A double-blinded, randomized, placebo controlled study. J. Clin. Lipidol. 2014, 8, 612-617. [CrossRef]

62. Ruiz-Núñez, B.; Dijck-Brouwer, D.J.; Muskiet, F.A. The relation of saturated fatty acids with low-grade inflammation and cardiovascular disease. J. Nutr. Biochem. 2016, 36, 1-20. [CrossRef]

63. Yokoi, H.; Mizukami, H.; Nagatsu, A.; Tanabe, H.; Inoue, M. Hydroxy monounsaturated fatty acids as agonists for peroxisome proliferator-activated receptors. Boil. Pharm. Bull. 2010, 33, 854-861. [CrossRef]

64. Perdomo, L.; Beneit, N.; Otero, Y.F.; Escribano, O.; Diaz-Castroverde, S.; Gómez-Hernández, A.; Benito, M. Protective role of oleic acid against cardiovascular insulin resistance and in the early and late cellular atherosclerotic process. Cardiovasc. Diabetol. 2015, 14, 75-87. [CrossRef]

65. Hlais, S.; El-Bistami, D.; El Rahi, B.; Mattar, M.A.; Obeid, O. Combined Fish Oil and High Oleic Sunflower Oil Supplements Neutralize their Individual Effects on the Lipid Profile of Healthy Men. Lipids 2013, 48, 853-861. [CrossRef] [PubMed]

66. Pérez-Martínez, P.; García-Ríos, A.; Delgado, F.G.; Jiménez, F.P.; López-Miranda, J. Mediterranean diet rich in olive oil and obesity, metabolic syndrome and diabetes mellitus. Curr. Pharm. Des. 2011, 17, 769-777. [CrossRef] [PubMed]

67. Kwon, B.; Lee, H.-K.; Querfurth, H.W. Oleate prevents palmitate-induced mitochondrial dysfunction, insulin resistance and inflammatory signaling in neuronal cells. Biochim. Biophys. Acta Bioenerg. 2014, 1843, 1402-1413. [CrossRef] [PubMed]

68. Salvadó, L.; Coll, T.; Gómez-Foix, A.M.; Salmerón, E.; Barroso, E.; Palomer, X.; Vázquez-Carrera, M. Oleate prevents saturated-fatty-acid-induced ER stress, inflammation and insulin resistance in skeletal muscle cells through an AMPK-dependent mechanism. Diabetology 2013, 56, 1372-1382. [CrossRef]

69. Jones, P.J.H.; Mackay, D.; Senanayake, V.K.; Pu, S.; Jenkins, D.J.A.; Connelly, P.; Lamarche, B.; Couture, P.; Kris-Etherton, P.M.; West, S.G.; et al. High-oleic canola oil consumption enriches LDL particle cholesteryl oleate content and reduces LDL proteoglycan binding in humans. Atherosclerosis 2014, 238, 231-238. [CrossRef] 
70. Harvey, K.A.; Walker, C.L.; Xu, Z.; Whitley, P.; Pavlina, T.M.; Hise, M.; Zaloga, G.P.; Siddiqui, R.A. Oleic acid inhibits stearic acid-induced inhibition of cell growth and pro-inflammatory responses in human aortic endothelial cells. J. Lipid Res. 2010, 51, 3470-3480. [CrossRef]

71. Duarte, M.K.R.N.; De Araújo, J.N.G.; Duarte, V.H.R.; De Oliveira, K.M.; De Oliveira, J.M.; Carioca, A.A.F.; Bortolin, R.H.; Rezende, A.A.; Hirata, M.H.; Hirata, R.D.C.; et al. The relationship of the oleic acid level and ECHDC3 mRNA expression with the extent of coronary lesion. Lipids Health Dis. 2016, 15, 144-150. [CrossRef]

72. Mozaffarian, D.; Wu, J.H.Y. Omega-3 Fatty Acids and Cardiovascular Disease. J. Am. Coll. Cardiol. 2011, 58, 2047-2067. [CrossRef]

73. Dyall, S.C. Long-chain omega-3 fatty acids and the brain: A review of the independent and shared effects of EPA, DPA and DHA. Front. Aging Neurosci. 2015, 7, 52-67. [CrossRef]

74. Calder, P.C. Omega-3 polyunsaturated fatty acids and inflammatory processes: Nutrition or pharmacology? Br. J. Clin. Pharmacol. 2013, 75, 645-662. [CrossRef]

75. Binia, A.; Vargas-Martínez, C.; Moreno, M.A.; Gosoniu, L.M.; Montoliu, I.; Gámez-Valdez, E.; Soria-Contreras, D.C.; Angeles-Quezada, A.; Gonzalez-Alberto, R.; Fernández, S.; et al. Improvement of cardiometabolic markers after fish oil intervention in young Mexican adults and the role of PPAR $\alpha 162 \mathrm{~V}$ and PPAR 2 P12A. J. Nutr. Biochem. 2017, 43, 98-106. [CrossRef] [PubMed]

76. Abdelhamid, A.; Brown, T.J.; Brainard, J.S.; Biswas, P.; Thorpe, G.C.; Moore, H.J.; Deane, K.; AlAbdulghafoor, F.K.; Summerbell, C.D.; Worthington, H.; et al. Omega-3 fatty acids for the primary and secondary prevention of cardiovascular disease. Cochrane Database Syst. Rev. 2018, 11, 1-745. [CrossRef]

77. Aung, T.; Halsey, J.; Kromhout, D.; Gerstein, H.C.; Marchioli, R.; Tavazzi, L.; Geleijnse, J.M.; Rauch, B.; Ness, A.; Galan, P.; et al. Associations of Omega-3 Fatty Acid Supplement Use With Cardiovascular Disease Risks: Meta-analysis of 10 Trials Involving 77917 Individuals. JAMA Cardiol. 2018, 3, 225-234. [CrossRef] [PubMed]

78. The ASCEND Study Collaborative Group. Effects of n-3 Fatty Acid Supplements in Diabetes Mellitus. N. Engl. J. Med. 2018, 379, 1540-1550. [CrossRef] [PubMed]

79. Manson, J.E.; Cook, N.R.; Lee, I.M.; Christen, W.; Bassuk, S.S.; Mora, S.; Gibson, H.; Albert, C.M.; Gordon, D.; Copeland, T.; et al. Marine Omega-3 Fatty Acids and Prevention of Vascular Disease and Cancer. N. Engl. J. Med. 2018, 380, 23-32. [CrossRef]

80. Pan, A.; Chen, M.; Chowdhury, R.; Wu, J.H.Y.; Sun, Q.; Campos, H.; Mozaffarian, D.; Hu, F.B. $\alpha$-Linolenic acid and risk of cardiovascular disease: A systematic review and meta-analysis. Am. J. Clin. Nutr. 2012, 96, 1262-1273. [CrossRef]

81. Bloedon, L.T.; Balikai, S.; Chittams, J.; Cunnane, S.C.; Berlin, J.A.; Rader, D.J.; Szapary, P.O. Flaxseed and cardiovascular risk factors: Results from a double blind, randomized, controlled clinical trial. J. Am. Coll. Nutr. 2008, 27, 65-74. [CrossRef]

82. Rajaram, S.; Haddad, E.H.; Mejia, A.; Sabaté, J. Walnuts and fatty fish influence different serum lipid fractions in normal to mildly hyperlipidemic individuals: A randomized controlled study. Am. J. Clin. Nutr. 2009, 89, 1657-1663. [CrossRef]

83. Djoussé, L.; Folsom, A.R.; Province, M.A.; Hunt, S.C.; Ellison, R.C. Dietary linolenic acid and carotid atherosclerosis: The National Heart, Lung, and Blood Institute Family Heart Study. Am. J. Clin. Nutr. 2003, 77, 819-825. [CrossRef]

84. Djoussé, L.; Arnett, D.K.; Carr, J.J.; Eckfeldt, J.H.; Hopkins, P.N.; Province, M.A.; Ellison, R.C. Dietary Linolenic Acid Is Inversely Associated With Calcified Atherosclerotic Plaque in the Coronary Arteries. Circulation 2005, 111, 2921-2926. [CrossRef]

85. Sala-Vila, A.; Cofán, M.; Pérez-Heras, A.; Nuñez, I.; Gilabert, R.; Junyent, M.; Mateo-Gallego, R.; Cenarro, A.; Civeira, F.; Ros, E. Fatty acids in serum phospholipids and carotid intima-media thickness in Spanish subjects with primary dyslipidemia. Am. J. Clin. Nutr. 2010, 92, 186-193. [CrossRef]

86. Park, Y.; Lim, J.; Kwon, Y.; Lee, J. Correlation of erythrocyte fatty acid composition and dietary intakes with markers of atherosclerosis in patients with myocardial infarction. Nutr. Res. 2009, 29, 391-396. [CrossRef] [PubMed]

87. Lemaitre, R.N.; King, I.B.; Sotoodehnia, N.; Rea, T.D.; Raghunathan, T.E.; Rice, K.M.; Lumley, T.S.; Knopp, R.H.; Cobb, L.A.; Copass, M.K.; et al. Red blood cell membrane $\alpha$-linolenic acid and the risk of sudden cardiac arrest. Metabolism 2009, 58, 534-540. [CrossRef] [PubMed] 
88. Rajaram, S. Health benefits of plant-derived $\alpha$-linolenic acid. Am. J. Clin. Nutr. 2014, 100, 443-448. [CrossRef] [PubMed]

89. Borow, K.M.; Nelson, J.R.; Mason, R.P. Biologic plausibility, cellular effects, and molecular mechanisms of eicosapentaenoic acid (EPA) in atherosclerosis. Atherosclerosis 2015, 242, 357-366. [CrossRef] [PubMed]

90. Itakura, H.; Yokoyama, M.; Matsuzaki, M.; Saito, Y.; Origasa, H.; Ishikawa, Y.; Oikawa, S.; Sasaki, J.; Hishida, H.; Kita, T.; et al. Relationships between plasma fatty acid composition and coronary artery disease. J. Atheroscler. Thromb. 2010, 18, 99-107. [CrossRef]

91. Bhatt, D.L.; Steg, P.G.; Miller, M.; Brinton, E.A.; Jacobson, T.A.; Ketchum, S.B.; Doyle, R.T.; Juliano, R.A.; Jiao, L.; Granowitz, C.; et al. Cardiovascular Risk Reduction with Icosapent Ethyl for Hypertriglyceridemia. N. Engl. J. Med. 2019, 380, 11-22. [CrossRef]

92. Mason, R.P.; Jacob, R.F.; Corbalan, J.J.; Malinski, T. Combination Eicosapentaenoic Acid and Statin Treatment Reversed Endothelial Dysfunction in HUVECs Exposed to Oxidized LDL. J. Clin. Lipidol. 2014, 8, 342-343. [CrossRef]

93. Ishida, T.; Naoe, S.; Nakakuki, M.; Kawano, H.; Imada, K. Eicosapentaenoic Acid Prevents Saturated Fatty Acid-Induced Vascular Endothelial Dysfunction: Involvement of Long-Chain Acyl-CoA Synthetase. J. Atheroscler. Thromb. 2015, 22, 1172-1185. [CrossRef]

94. Lee, C.H.; Lee, S.D.; Ou, H.C.; Lai, S.C.; Cheng, Y.-J. Eicosapentaenoic Acid Protects against Palmitic Acid-Induced Endothelial Dysfunction via Activation of the AMPK/eNOS Pathway. Int. J. Mol. Sci. 2014, 15, 10334-10349. [CrossRef]

95. Mason, R.P.; Jacob, R.; Beauregard, G.; Rowe, J. Comparative Lipid Antioxidant Effects of Omega-3 Fatty Acids in Combination with HMG-CoA Reductase Inhibitors. J. Clin. Lipidol. 2011, 5, 201. [CrossRef]

96. Mason, R.P.; Jacob, R.F. Eicosapentaenoic acid inhibits glucose-induced membrane cholesterol crystalline domain formation through a potent antioxidant mechanism. Biochim. Biophys. Acta Biomembr. 2015, 1848, 502-509. [CrossRef] [PubMed]

97. Chiu, S.-C.; Chiang, E.; Tsai, S.-Y.; Wang, F.-Y.; Pai, M.-H.; Syu, J.-N.; Cheng, C.-C.; Rodriguez, R.L.; Tang, F.-Y. Eicosapentaenoic acid induces neovasculogenesis in human endothelial progenitor cells by modulating c-kit protein and PI3-K/Akt/eNOS signaling pathways. J. Nutr. Biochem. 2014, 25, 934-945. [CrossRef] [PubMed]

98. Budoff, M.J. Triglycerides and Triglyceride-Rich Lipoproteins in the Causal Pathway of Cardiovascular Disease. Am. J. Cardiol. 2016, 118, 138-145. [CrossRef]

99. Gdula-Argasińska, J.; Czepiel, J.; Woźniakiewicz, A.; Wojtoń, K.; Grzywacz, A.; Woźniakiewicz, M.; Jurczyszyn, A.; Perucki, W.; Librowski, T. n-3 Fatty acids as resolvents of inflammation in the A549 cells. Pharmacol. Rep. 2015, 67, 610-615. [CrossRef]

100. Nelson, J.R.; Wani, O.; May, H.; Budoff, M. Potential benefits of eicosapentaenoic acid on atherosclerotic plaques. Vasc. Pharmacol. 2017, 91, 1-9. [CrossRef]

101. Cawood, A.L.; Ding, R.; Napper, F.L.; Young, R.H.; Williams, J.A.; Ward, M.J.; Gudmundsen, O.; Vige, R.; Payne, S.P.; Ye, S.; et al. Eicosapentaenoic acid (EPA) from highly concentrated n-3 fatty acid ethyl esters is incorporated into advanced atherosclerotic plaques and higher plaque EPA is associated with decreased plaque inflammation and increased stability. Atherosclerosis 2010, 212, 252-259. [CrossRef]

102. Katoh, A.; Ikeda, H. Daily intake of eicosapentaenoic acid inhibits the progression of carotid intimal-media thickness in patients with dyslipidemia. Ther. Res. 2011, 32, 863-868.

103. Maeda, K. Effect of highly purified eicosapentaenoic acid (EPA) for patients with multiple artery atherosclerotic risk factors and clinical usefulness of the ratio of serum EPA to arachidonic acid (AA) as the indicator of therapy effect of atherosclerosis. Ther. Res. 2014, 35, 177-182.

104. Hasturk, H.; Abdallah, R.; Kantarci, A.; Nguyen, D.; Giordano, N.; Hamilton, J.; Van Dyke, T.E. Resolvin E1 (RvE1) Attenuates Atherosclerotic Plaque Formation in Diet and Inflammation-Induced Atherogenesis. Arter. Thromb. Vasc. Boil. 2015, 35, 1123-1133. [CrossRef]

105. Spite, M.; Claria, J.; Serhan, C.N. Resolvins, specialized proresolving lipid mediators, and their potential roles in metabolic diseases. Cell Metab. 2013, 19, 21-36. [CrossRef] [PubMed]

106. Adkins, Y.; Kelley, D.S. Mechanisms underlying the cardioprotective effects of omega-3 polyunsaturated fatty acids. J. Nutr. Biochem. 2010, 21, 781-792. [CrossRef] [PubMed]

107. Singh, S.; Arora, R.R.; Singh, M.; Khosla, S. Eicosapentaenoic Acid Versus Docosahexaenoic Acid as Options for Vascular Risk Prevention. Am. J. Ther. 2016, 23, 905-910. [CrossRef] [PubMed] 
108. Phang, M.; Lazarus, S.; Wood, L.G.; Garg, M. Diet and Thrombosis Risk: Nutrients for Prevention of Thrombotic Disease. Semin. Thromb. Hemost. 2011, 37, 199-208. [CrossRef]

109. Qi, K.; Fan, C.; Jiang, J.; Zhu, H.; Jiao, H.; Meng, Q.; Deckelbaum, R.J. Omega-3 fatty acid containing diets decrease plasma triglyceride concentrations in mice by reducing endogenous triglyceride synthesis and enhancing the blood clearance of triglyceride-rich particles. Clin. Nutr. 2008, 27, 424-430. [CrossRef]

110. Honda, K.L.; Lamon-Fava, S.; Matthan, N.R.; Wu, D.; Lichtenstein, A.H. Docosahexaenoic acid differentially affects TNF $\alpha$ and IL-6 expression in LPS-stimulated RAW 264.7 murine macrophages. Prostaglandins Leukot. Essent. Fat. Acids 2015, 97, 27-34. [CrossRef]

111. Wang, Z.; Guo, A.; Ma, L.; Yu, H.; Zhang, L.; Meng, H.; Cui, Y.; Yu, F.; Yang, B. Docosahexenoic acid treatment ameliorates cartilage degeneration via a p38 MAPK-dependent mechanism. Int. J. Mol. Med. 2016, 37, 1542-1550. [CrossRef]

112. Yang, Y.C.; Lii, C.K.; Wei, Y.L.; Li, C.C.; Lu, C.Y.; Liu, K.L.; Chen, H.-W. Docosahexaenoic acid inhibition of inflammation is partially via cross-talk between Nrf2/heme oxygenase 1 and IKK/NF- $\mathrm{kB}$ pathways. J. Nutr. Biochem. 2013, 24, 204-212. [CrossRef]

113. Fahs, C.A.; Yan, H.; Ranadive, S.; Rossow, L.M.; Agiovlasitis, S.; Wilund, K.R.; Fernhall, B. The effect of acute fish-oil supplementation on endothelial function and arterial stiffness following a high-fat meal. Appl. Physiol. Nutr. Metab. 2010, 35, 294-302. [CrossRef]

114. Asztalos, I.B.; Gleason, J.A.; Sever, S.; Gedik, R.; Asztalos, B.F.; Horvath, K.V.; Dansinger, M.L.; Lamon-Fava, S.; Schaefer, E.J.; Information, P.E.K.F.C. Effects of eicosapentaenoic acid and docosahexaenoic acid on cardiovascular disease risk factors: A randomized clinical trial. Metabolism 2016, 65, 1636-1645. [CrossRef]

115. Backes, J.M.; Anzalone, D.; Hilleman, D.; Catini, J. The clinical relevance of omega-3 fatty acids in the management of hypertriglyceridemia. Lipids Health Dis. 2016, 15, 118-130. [CrossRef]

116. Otto, M.C.D.O.; Wu, J.H.Y.; Baylin, A.; Vaidya, D.; Rich, S.S.; Tsai, M.; Jacobs, D.R.; Mozaffarian, D. Circulating and Dietary Omega-3 and Omega-6 Polyunsaturated Fatty Acids and Incidence of CVD in the Multi-Ethnic Study of Atherosclerosis. J. Am. Hear. Assoc. 2013, 2, 1-17. [CrossRef]

117. Kaur, G.; Cameron-Smith, D.; Garg, M.; Sinclair, A.J. Docosapentaenoic acid (22:5n-3): A review of its biological effects. Prog. Lipid Res. 2011, 50, 28-34. [CrossRef] [PubMed]

118. Drouin, G.; Rioux, V.; Legrand, P.; Gaetan, D.; Vincent, R.; Legrand, P. The $\mathrm{n}-3$ docosapentaenoic acid (DPA): A new player in the $\mathrm{n}-3$ long chain polyunsaturated fatty acid family. Biochimie 2019, 159, 36-48. [CrossRef] [PubMed]

119. Sun, Q.; Ma, J.; Campos, H.; Rexrode, K.M.; Albert, C.M.; Mozaffarian, D.; Hu, F.B. Blood concentrations of individual long-chain n-3 fatty acids and risk of nonfatal myocardial infarction. Am. J. Clin. Nutr. 2008, 88, 216-223. [CrossRef] [PubMed]

120. Mozaffarian, D.; Lemaitre, R.N.; King, I.B.; Song, X.; Spiegelman, D.; Sacks, F.M.; Rimm, E.B.; Siscovick, D.S. Circulating Long-Chain $\omega-3$ Fatty Acids and Incidence of Congestive Heart Failure in Older Adults: The Cardiovascular Health Study. Ann. Intern. Med. 2011, 155, 160-170. [CrossRef] [PubMed]

121. Amano, T.; Matsubara, T.; Uetani, T.; Kato, M.; Kato, B.; Yoshida, T.; Harada, K.; Kumagai, S.; Kunimura, A.; Shinbo, Y.; et al. Impact of omega-3 polyunsaturated fatty acids on coronary plaque instability: An integrated backscatter intravascular ultrasound study. Atherosclerosis 2011, 218, 110-116. [CrossRef]

122. Jackson, S.P. The growing complexity of platelet aggregation. Blood 2007, 109, 5087-5095. [CrossRef]

123. Phang, M.; Garg, M.L.; Sinclair, A.J. Inhibition of platelet aggregation by omega-3 polyunsaturated fatty acids is gender specific-Redefining platelet response to fish oils. Prostaglandins Leukot. Essent. Fat. Acids 2009, 81, 35-40. [CrossRef]

124. Yazdi, P.G. A review of the biologic and pharmacologic role of docosapentaenoic acid n-3. F1000Research 2014, 2, 256-264. [CrossRef]

125. Tribulova, N.; Bacova, B.S.; Benova, T.E.; Knezl, V.; Barancik, M.; Slezak, J. Omega-3 Index and Anti-Arrhythmic Potential of Omega-3 PUFAs. Nutrients 2017, 9, 1191. [CrossRef] [PubMed]

126. Tortosa-Caparrós, E.; Navas-Carrillo, D.; Marín, F.; Orenes-Piñero, E. Anti-inflammatory effects of omega 3 and omega 6 polyunsaturated fatty acids in cardiovascular disease and metabolic syndrome. Crit. Rev. Food Sci. Nutr. 2016, 57, 3421-3429. [CrossRef] 
127. Chowdhury, R.; Warnakula, S.; Kunutsor, S.K.; Crowe, F.; Ward, H.A.; Johnson, L.; Franco, O.H.; Butterworth, A.S.; Forouhi, N.G.; Thompson, S.G.; et al. Association of dietary, circulating, and supplement fatty acids with coronary risk: A systematic review and meta-analysis. Ann. Intern. Med. 2014, 160, 398-406. [CrossRef] [PubMed]

128. De Lorgeril, M.E. Essential Polyunsaturated Fatty Acids, Inflammation, Atherosclerosis and Cardiovascular Diseases. Alzheimer's Dis. 2007, 42, 283-297. [CrossRef]

129. Hooper, C.L.; Al-Khudairy, L.; Abdelhamid, A.; Rees, K.; Brainard, J.S.; Brown, T.; Ajabnoor, S.M.; O’Brien, A.T.; Winstanley, L.E.; Donaldson, D.H.; et al. Omega-6 fats for the primary and secondary prevention of cardiovascular disease. Cochrane Database Syst. Rev. 2018, 7, 1-204. [CrossRef]

130. Harris, W.S.; Shearer, G.C. Omega-6 Fatty Acids and Cardiovascular Disease. Circulation 2014, 130, $1562-1564$. [CrossRef]

131. Kłosiewicz-Latoszek, L.; Szostak, W.B.; Podolec, P. Nutrition Guidelines of Polish Forum of Circulation System Disease Prophylaxis. Available online: www.pfp.edu.pl (accessed on 30 April 2014).

132. Allayee, H.; Roth, N.; Hodis, H.N. Polyunsaturated fatty acids and cardiovascular disease: Implications for nutrigenetics. J. Nutr. Nutr. 2009, 2, 140-148. [CrossRef] [PubMed]

133. Deckelbaum, R.J.; Calder, P.C. Dietary n-3 and n-6 fatty acids: Are there 'bad' polyunsaturated fatty acids? Curr. Opin. Clin. Nutr. Metab. Care 2010, 13, 123-124. [CrossRef]

134. Simopoulos, A.P. The Importance of the Omega-6/Omega-3 Fatty Acid Ratio in Cardiovascular Disease and Other Chronic Diseases. Exp. Boil. Med. 2008, 233, 674-688. [CrossRef]

135. Blasbalg, T.L.; Hibbeln, J.R.; Ramsden, C.E.; Majchrzak, S.F.; Rawlings, R.R. Changes in consumption of omega-3 and omega-6 fatty acids in the United States during the 20th century. Am. J. Clin. Nutr. 2011, 93, 950-962. [CrossRef]

136. Serhan, C.N.; Yacoubian, S.; Yang, R. Anti-inflammatory and proresolving lipid mediators. Annu. Rev. Pathol. Mech. Dis. 2008, 3, 279-312. [CrossRef] [PubMed]

137. Johnson, G.H.; Fritsche, K. Effect of Dietary Linoleic Acid on Markers of Inflammation in Healthy Persons: A Systematic Review of Randomized Controlled Trials. J. Acad. Nutr. Diet. 2012, 112, 1029-1041. [CrossRef] [PubMed]

138. Ferrucci, L.; Cherubini, A.; Bandinelli, S.; Bartali, B.; Corsi, A.; Lauretani, F.; Martín, A.; Andres-Lacueva, C.; Senin, U.; Guralnik, J.M. Relationship of Plasma Polyunsaturated Fatty Acids to Circulating Inflammatory Markers. J. Clin. Endocrinol. Metab. 2006, 91, 439-446. [CrossRef] [PubMed]

139. ERA-JUMP Study Group; Choo, J.; Ueshima, H.; Curb, J.D.; Shin, C.; Evans, R.W.; El-Saed, A.; Kadowaki, T.; Okamura, T.; Nakata, K.; et al. Serum n-6 fatty acids and lipoprotein subclasses in middle-aged men: The population-based cross-sectional ERA-JUMP Study. Am. J. Clin. Nutr. 2010, 91, 1195-1203. [CrossRef] [PubMed]

140. Ramsden, E.; Zamora, C.; Majchrzak-Hong, D.; Faurot, S.; Broste, K.R.; Frantz, S.K.; Davis, R.P.; Ringel, J.M.; Suchindran, A.; Hibbeln, C.M.; et al. Re-evaluation of the traditional diet-heart hypothesis: Analysis of recovered data from Minnesota Coronary Experiment (1968-1973). BMJ 2016, 353, 1246-1263. [CrossRef] [PubMed]

141. Harris, W.S.; Poston, W.C.; Haddock, C.K. Tissue $\mathrm{n}-3$ and $\mathrm{n}-6$ fatty acids and risk for coronary heart disease events. Atherosclerosis 2007, 193, 1-10. [CrossRef]

142. Sergeant, S.; Rahbar, E.; Chilton, F.H. Gamma-linolenic acid, Dihommo-gamma linolenic, Eicosanoids and Inflammatory Processes. Eur. J. Pharmacol. 2016, 785, 77-86. [CrossRef]

143. Białek, M.; Rutkowska, J. The importance of $\gamma$-linolenic acid in the prevention and treatment- Text: Electronic. Postepy Hig. Med. Dosw. 2015, 69, 892-904. [CrossRef]

144. Nyalala, J.O.; Wang, J.; Dang, A.; Faas, F.H.; Smith, W.G. Hypertriglyceridemia and hypercholesterolemia: Effects of drug treatment on fatty acid composition of plasma lipids and membranes. Prostaglandins Leukot. Essent. Fat. Acids 2008, 78, 271-280. [CrossRef]

145. Schwab, U.; Callaway, J.C.; Erkkilä, A.T.; Gynther, J.; Uusitupa, M.I.; Järvinen, T. Effects of hempseed and flaxseed oils on the profile of serum lipids, serum total and lipoprotein lipid concentrations and haemostatic factors. Eur. J. Nutr. 2006, 45, 470-477. [CrossRef]

146. Das, U.N. Essential fatty acids and their metabolites in the context of hypertension. Hypertens. Res. 2010, 33, 782-785. [CrossRef] [PubMed] 
147. Dennis, E.A.; Cao, J.; Hsu, Y.H.; Magrioti, V.; Kokotos, G. Phospholipase A2Enzymes: Physical Structure, Biological Function, Disease Implication, Chemical Inhibition, and Therapeutic Intervention. Chem. Rev. 2011, 111, 6130-6185. [CrossRef] [PubMed]

148. Le, H.D.; Meisel, J.A.; De Meijer, V.E.; Gura, K.M.; Puder, M. The essentiality of arachidonic acid and docosahexaenoic acid. Prostaglandins Leukot. Essent. Fat. Acids 2009, 81, 165-170. [CrossRef] [PubMed]

149. Shanab, S.M.; Hafez, R.; Fouad, A.S. A review on algae and plants as potential source of arachidonic acid. J. Adv. Res. 2018, 11, 3-13. [CrossRef]

150. Tallima, H.; El Ridi, R. Arachidonic acid: Physiological roles and potential health benefits-A review. J. Adv. Res. 2018, 11, 33-41. [CrossRef]

151. Kawanabe, A.; Okamura, Y. Effects of unsaturated fatty acids on the kinetics of voltage-gated proton channels heterologously expressed in cultured cells. J. Physiol. 2016, 594, 595-610. [CrossRef]

152. Sonnweber, T.; Tancevski, I.; Nairz, M.; Weiss, G.; Tancevski, I. Arachidonic Acid Metabolites in Cardiovascular and Metabolic Diseases. Int. J. Mol. Sci. 2018, 19, 3285. [CrossRef]

153. Tsukamoto, I.; Sugawara, S. Low levels of linoleic acid and $\alpha$-linolenic acid and high levels of arachidonic acid in plasma phospholipids are associated with hypertension. Biomed. Rep. 2017, 8, 69-76. [CrossRef]

154. Claria, J.; Nguyen, B.T.; Madenci, A.L.; Ozaki, C.K.; Serhan, C.N. Diversity of lipid mediators in human adipose tissue depots. Am. J. Physiol. Physiol. 2013, 304, 1141-1149. [CrossRef]

155. Inoue, K.; Kishida, K.; Hirata, A.; Funahashi, T.; Shimomura, I. Low serum eicosapentaenoic acid / arachidonic acid ratio in male subjects with visceral obesity. Nutr. Metab. 2013, 10, 25-33. [CrossRef]

156. Wolters, M.; Pala, V.; Russo, P.; Risé, P.; Moreno, L.A.; De Henauw, S.; Mehlig, K.; Veidebaum, T.; Molnar, D.; Tornaritis, M.; et al. Associations of Whole Blood n-3 and n-6 Polyunsaturated Fatty Acids with Blood Pressure in Children and Adolescents-Results from the IDEFICS/I.Family Cohort. PLoS ONE 2016, 11, e0165981. [CrossRef] [PubMed]

(C) 2020 by the authors. Licensee MDPI, Basel, Switzerland. This article is an open access article distributed under the terms and conditions of the Creative Commons Attribution (CC BY) license (http://creativecommons.org/licenses/by/4.0/). 